\title{
ACCURACY OF PEDICLE SCREW INSERTION: A COMPARISON BETWEEN FLUOROSCOPIC GUIDANCE AND NAVIGATION TECHNIQUES
}

\section{ACURÁCIA DA INSERÇÃO DE PARAFUSOS PEDICULARES COMPARANDO FLUOROSCOPIA E NAVEGAÇÃO}

\author{
Romero Pinto de Oliveira Bilhar ${ }^{1}$, Diego Ariel de Lima ${ }^{1}$, José Alberto Dias Leite ${ }^{1}$, Maximiliano Aguiar Porto ${ }^{1}$ \\ 1. Universidade Federal do Ceará, Faculdade de Medicina, Department of Orthopedics and Traumatology, Fortaleza, CE, Brazil.
}

\section{ABSTRACT}

Objectives: To compare the accuracy of insertion of pedicle screws into the thoracic spine using fluoroscopic guidance or computer-assisted navigation techniques. Methods: Eight cadaveric thoracic spines were divided into two groups: the fluoroscopy group, in which pedicle screws were inserted with the guidance of a C-arm device, and the navigation group, in which insertion of the screws was monitored using computer-assisted navigation equipment. All procedures were performed by the same spinal surgeon. The rate of pedicle breach was compared between the two groups. Results: There was one intra-canal perforation in each group. Both perforations were medial in direction, and the breaches were 2 to $4 \mathrm{~mm}$ deep. There were no statistically significant differences in breach rate between the two groups. Conclusions: The accuracy of insertion of pedicle screws in the thoracic spine using computer-assisted navigation is equivalent to that achieved using fluoroscopic guidance. Computer-assisted navigation improves the safety of the surgical team during the procedure due to the absence of exposure to radiation. Therefore, there is a need for future randomized controlled trials to be conducted in the clinical setting to evaluate other outcomes, including duration of surgery and blood loss during the procedure. Level of evidence IV.

Keywords: Pedicle screw. Spine. Spinal fusion. Neuronavigation. Fluoroscopy.

\section{RESUMO}

Objetivos: Comparar a acurácia da inserção de parafusos pediculares na coluna torácica, utilizando fluoroscopia ou técnicas de navegação assistidas por computador. Métodos: Estudo experimental com cadáveres. Oito colunas torácicas proveniente de cadáveres foram divididas em dois grupos: no grupo Fluoroscopia os parafusos pediculares foram inseridos com orientação de um aparelho tipo C-arm, e no grupo Navegação o monitoramento foi feito com um equipamento de assistência por computador. Todos os procedimentos foram feitos pelo mesmo cirurgião de coluna. A taxa de violação do canal foi comparada entre os grupos. Resultados: Houve uma perfuração de canal em cada grupo, ambas mediais, com 2-4 mm de profundidade. Não houve diferenças significativas entre os dois grupos em termos de taxa de perfuração do canal. Conclusão: A acurácia na inserção de parafusos pediculares na coluna torácica é igual comparando-se a navegação assistida por computador e o método de monitoramento por fluoroscopia. Como a segurança do procedimento para a equipe cirúrgica é maior com o método da navegação, devido à ausência de exposição à radiação, há necessidade de se realizarem estudos clínicos controlados no ambiente clínico, que avaliem outros desfechos, como o tempo de cirurgia e de sangramento. Nível de evidência IV.

Descritores: Parafusos Pediculares. Coluna Vertebral. Fusão Vertebral. Neuronavegação. Fluoroscopia.

Citation: Bilhar RPO, Lima DA, Leite JAD, Porto MA. Accuracy of pedicle screw insertion: a comparison between fluoroscopic guidance and navigation techniques. Acta Ortop Bras. [online]. 2018;26(6):397-400. Available from URL: http://www.scielo.br/aob.

\section{INTRODUCTION}

Pedicle screw fixation plays an important role in many spinal surgeries, providing superior post-operative spinal stability. Stabilization methods for better consolidation of arthrodesis evolved through the decades. ${ }^{1-3}$ Pedicle screw instrumentation was used by Roy-Camille in the 1960s and 1970s however, it was with the work by Cotrel-Dubousset, in the 1980s, that pedicle screw fixation gained popularity as the third generation of spine instrumentation. ${ }^{2}$ In 1998, pedicle screw instrumentation was downclassified from an FDA Class III to Class II, and has been since then gaining popularity. This technology is now the standard care in arthrodesis of the thoracolumbar spine, due to the improved fusion rates and rigidity provided by these constructs. ${ }^{1,2}$ Studies have found that pedicle screws are biomechanically advantageous when compared to the previously used rod and hook systems. ${ }^{3}$ As the morphology of the pedicle is complex and due to its proximity to a number of significant tissues (e.g., the spinal cord and nerve roots), screw misplacement might lead not only to a decreased stability but also to neurological, vascular, and visceral injuries. ${ }^{4}$ Many surgeons

All authors declare no potential conflict of interest related to this article.

Work was conducted at the Department of Orthopedics and Traumatology, Faculdade de Medicina da Universidade Federal do Ceará, Ceará, Brazil. Correspondence: Romero Pinto de Oliveira Bilhar. ARS Orthopaedica. Rua Carolina Sucupira, 1086, Fortaleza, CE, Brazil. 60140-120. romerobilhar@hotmail.com 
consider the majority of cortical violations to be clinically silent depending on the location and the length of penetration ${ }^{5}$ — that can be categorized according to the length of perforation (up to $2 \mathrm{~mm}, 2-4 \mathrm{~mm}$ or greater than $4 \mathrm{~mm}$ ). ${ }^{6}$ However, even those initially silent perforations may be responsible for instability of the biomechanical construct, reduced fusion rates, or accelerated adjacent-level degeneration. ${ }^{7}$ The normal anatomy is naturally complex, and pedicles can be difficult to instrument due to pathological abnormalities. Scoliosis, rotation and asymmetric compression of vertebrae can significantly alter pedicle anatomy and complicate pedicle screw placement. ${ }^{8}$ The freehand technique for the placement of the pedicle screw is essentially a blind technique that depends on the correct identification of anatomical landmarks and experience of the surgeon to ensure proper insertion. Misplacement rates have been reported to range from $5 \%$ to $41 \%$ in the lumbar spine and from $3 \%$ to $55 \%$ in the thoracic spine when using conventional techniques. ${ }^{1,9} \mathrm{~A}$ recent review on the subject brings us the result of nine studies based on the freehand technique insertion of pedicle screws in the thoracolumbar spine, revealing an accuracy rate of $71.9 \%$ to $98.3 \%{ }^{10}$ Due to the difficulties and risks inherent to the implant insertion, new techniques have been developed to decrease the rate of misplaced screws and to increase the accuracy of positioning. ${ }^{10}$ The technology more widely used is the intraoperative fluoroscopic C-arm. ${ }^{11}$ Studies have generally shown that accuracy rates of screws placed with this technique have ranged from as low as $27.6 \%$ to above $90 \% .{ }^{12}$ Fluoroscopy-assisted instrumentation has a much smaller learning curve when compared with the freehand technique. In theory, the error rate should be lower, since fluoroscopy can give surgeons a chance to correct the mistakes before inserting the screw..$^{10}$ However, this additional safety mechanism is associated with potential safety disadvantages, as the increased exposure of the surgeon and his staff to radiation. ${ }^{13,14}$

Alternatively, a monitoring method that came up with the aim of increasing the accuracy of screws insertion and reducing exposure to radiation was computer-assisted navigation. ${ }^{15,16}$ Following the introduction of CT-guided spinal navigation (O-arm), numerous reports in the literature have been published demonstrating its utility in increasing the accuracy of pedicle screw placement and, at the same time, decreasing the incidence of neurological injury from misplaced pedicle screws. ${ }^{15,16}$ There have been many studies about pedicle screw placement accuracy with this technique, but due to differing definitions of breach and the lack of control groups, many of these studies are difficult to compare. ${ }^{10}$ Therefore, there is a shortage of direct comparison studies with standardized methodology.

\section{OBJECTIVE}

The objective of this experimental study was to compare the accuracy of insertion of pedicle screws in the thoracic spine using fluoroscopy or computer-assisted navigation techniques.

\section{MATERIALS AND METHODS}

\section{Ethical Committee}

This study was submitted to the Ethical Committee through the Plataforma Brasil by the CAAE 37515014.3.0000.5054 and approved with the protocol 1.000 .463 on $03 / 24 / 2015$

\section{Study design and setting}

This is an experimental study with unclaimed fresh cadavers, obtained from the local Forensic Institute. Only the thoracic vertebrae of the cadavers were used. Cadavers presenting spinal trauma or important spinal deformities were excluded. The project was approved by the Research Ethics Committee of the Walter Cantídio University Hospital, where the experiments took place, and all institutional and governmental regulations concerning the ethical use of human cadavers were followed.

\section{MATERIALS}

Eight fresh cadavers were obtained, male and female. They were dissected in the prone position for median longitudinal posterior access. A section of the thoracic spine, with five vertebrae in each sample, was removed. They were divided into two groups of four pieces each (the Fluoroscopy versus the Navigation group), totaling 20 vertebrae or 40 pedicles per group.

In both groups, polyaxial pedicle screws, with a diameter of 4.0 $\mathrm{mm}$ and lengths of 30 and $35 \mathrm{~mm}$, were used.

For imaging, the fluoroscopy equipment used was Fluorostar 7900 (GE, Salt Lake City, UT, USA). The navigation device was the Aimnav (Micromar, Diadema, SP, Brazil).

\section{METHODS}

All vertebrae samples in the Navigation group were submitted to computed tomography (CT) scans before the surgical experiment. All the pieces were then positioned on the surgical table and fixed by positioners used for hip replacement surgery (Figure 1) for operations. The same surgeon performed all procedures.

In the Fluoroscopy group, the screws were inserted with the guidance of a combination of anterior-posterior and lateral view images (Figure 2). In the Navigation group, the screws were inserted using a computer assisted navigation system. CT scans from the Navigation group were inserted into the navigation software and selected points were marked for navigator calibration (Figures 3 and 4).

After the screws have been inserted, the pieces were dissected and examined in search of pedicle breaches. Violations were registered as medial (intracanal), inferior (foraminal), lateral, superior or anterior cortical.

\section{Statistical analysis}

The violation cases were recorded as frequencies. The rates of pedicle breach were compared in both groups using the exact Fisher test (as the number of expected events was below 5). A significant value of $p<0.05$ was adopted.

\section{RESULTS}

No cadaver presented morphological abnormalities that would justify exclusion from the experiment. A total of 80 pedicle screws were inserted, 40 in each group. A total of 350 fluoroscopic images were necessary in the Fluoroscopy group, 8.75 per screw or pedicle in average. No fluoroscopy image was produced in the navigation group. In the Fluoroscopy group, 1 out of 40 screws was misplaced (2,5\%). This was a medial cortical breach, between 2-4 mm. In the Navigation group, there was also 1 case of pedicle violation (2,5\%), of equal position and size of perforation (Figure 5).

No statistically significant differences between the two methods were found ( $p>0.05)$.

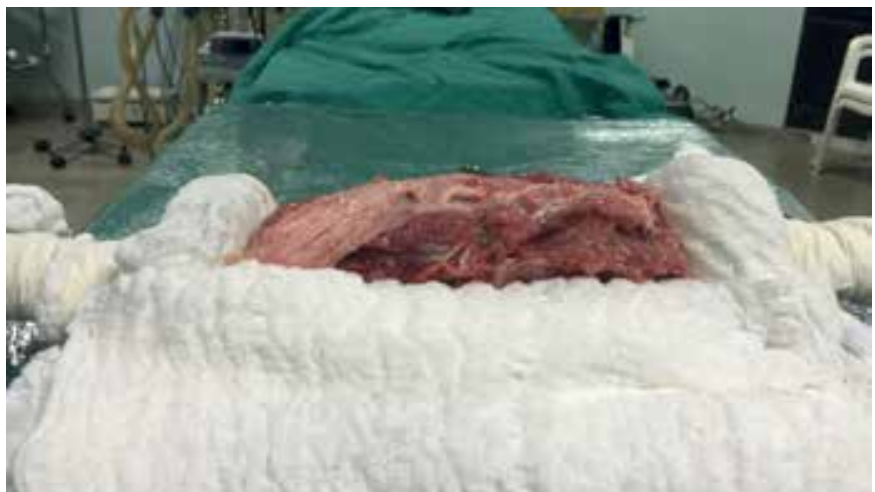

Figure 1. Spine section (1) prepared to be dissected and instrumented, fixed by retractors (2). 


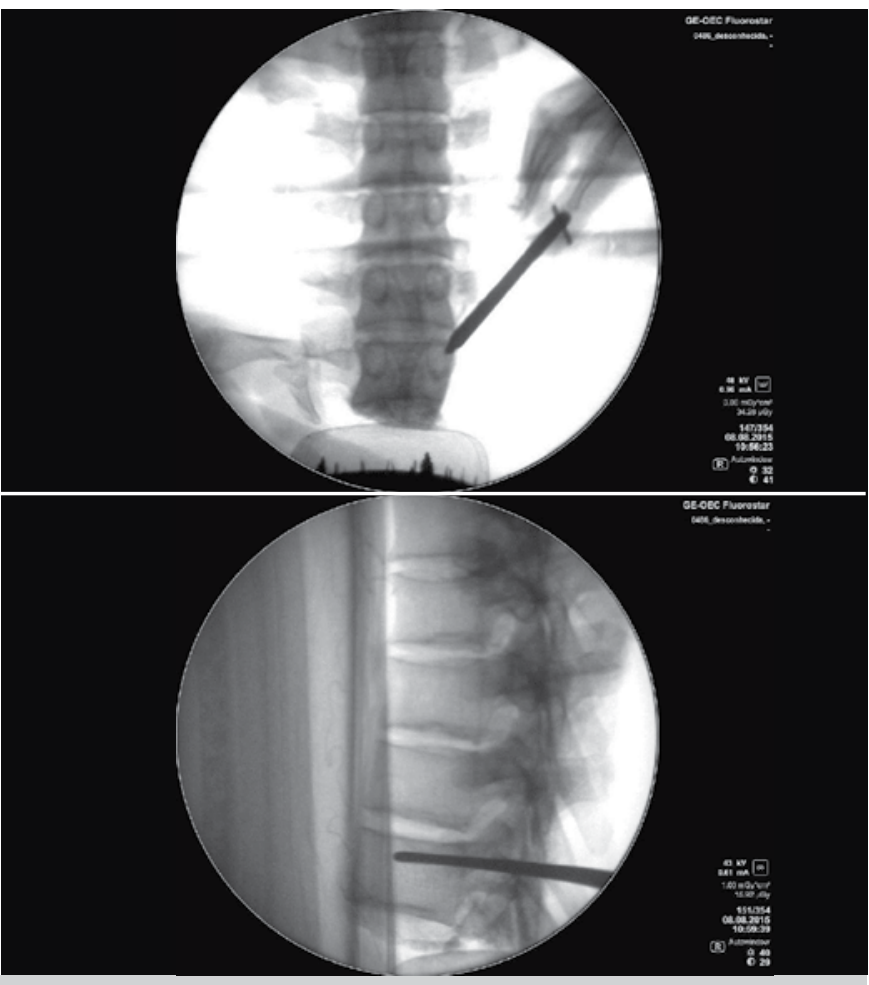

Figure 2. Fluoroscopic image on frontal view (left) showing an appropriate entry point in the upper-side corner of the pedicle projection, and on lateral view (right) showing good positioning of drilling.
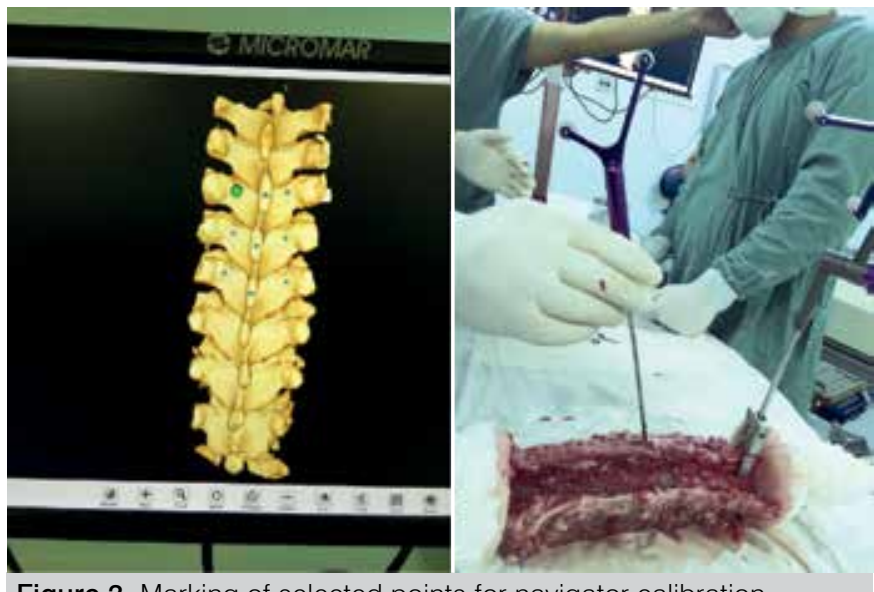

Figure 3. Marking of selected points for navigator calibration

\section{DISCUSSION}

Fluoroscopy is currently the most widely used method of pedicle screws insertion. ${ }^{11}$ However, as mentioned above, it has some intrinsic disadvantages, such as the amount of radiation to which the surgical team is exposed. . $^{13,17}$ Numerous studies show good accuracy rates in the insertion of pedicle screws with computer-assisted navigation when compared to the conventional method of fluoroscopy, but the superiority of navigation in terms of insertion accuracy is still doubtful, with variable breach rates between studies. ${ }^{18}$

Laine et al. ${ }^{19}$ demonstrated a greater misplacement rate in fluoroscopy group (13.4\%) when compared to the navigation (4.6\%). However, in that study, rates were not significantly different when only the breaches greater than $4 \mathrm{~mm}$ were considered (1.4\% in fluoroscopy group versus $0 \%$ in the navigation group). Another study also found superior accuracy in the screws insertion with computer-assisted navigation

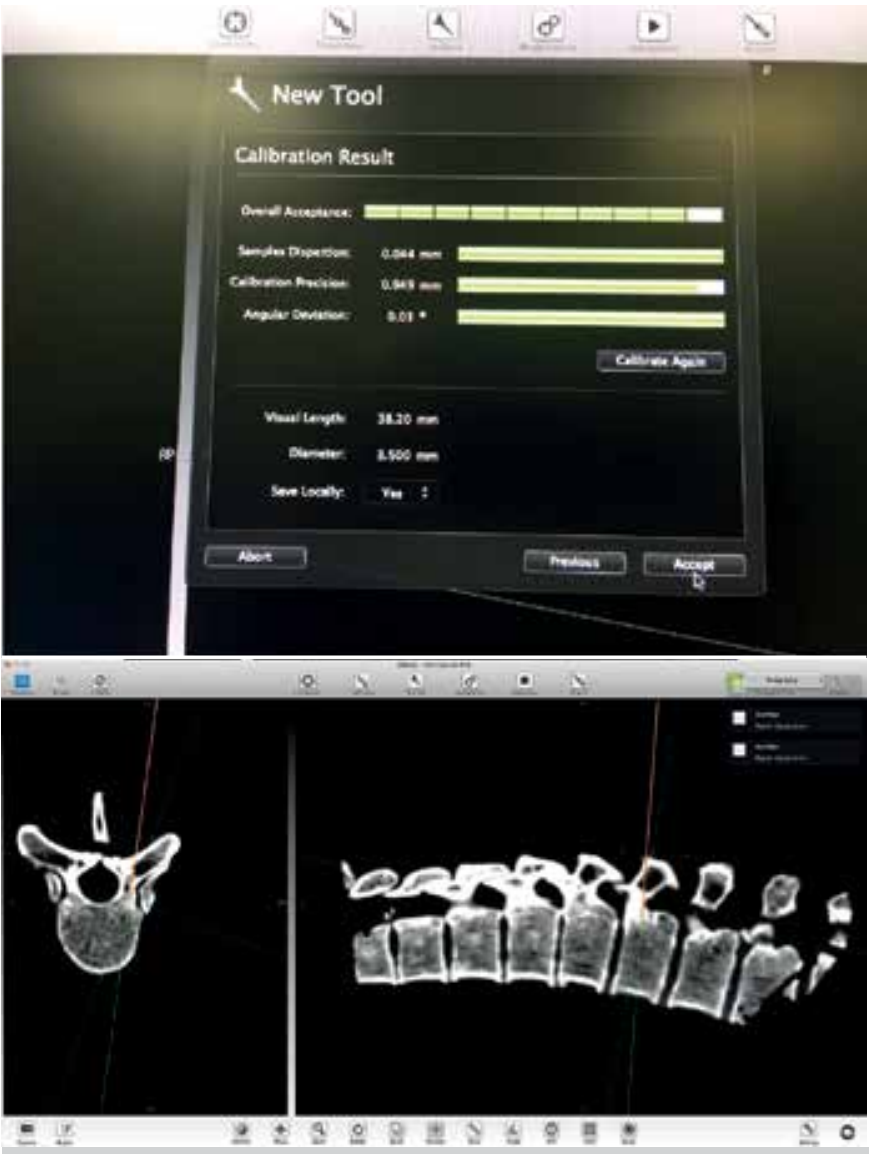

Figure 4. Computer screen showing a satisfactory result of calibration $(A)$ and axial $(B)$ and lateral view $(C)$ representing, in orange color, the already drilled path and, in green, the projection path.

( $2 \%$ of breach rate versus $23 \%$ with use of fluoroscopy). ${ }^{20}$ Tabaraee et al. ${ }^{13}$ conducted an experimental study in cadaver, similar to the present study, performing a direct comparison of the two methods, and also found no statistically significant differences between the groups. In a meta-analysis of 130 studies involving clinical and cadaveric, prospective and retrospective studies, there were no statistically significant differences between the insertion of screws by two methods in the thoracic spine. ${ }^{15}$ Another systematic review of 30 studies, more recently published, found greater accuracy in the insertion of pedicle screws with navigation (84.3\%) compared to fluoroscopy (68.1\%). However, only 1 of the 30 studies was a randomized controlled trial. All others were only level 3 (observational studies with control groups) and 4 (observational studies). ${ }^{21}$ The comparison between studies, is difficult, due to lack of standardization of the imaging methods and the lack of uniform criteria for classifying the violations as events. ${ }^{19}$ Different screw misplacement grading systems are used to assess the screw placement accuracy, but usually including the following categories: Grade 0, no pedicle perforation; Grade 1, perforation of 0-2 mm; Grade 2, 2-4 mm; Grade 3, perforation greater than $4 \mathrm{~mm}^{6}$

Another cause of the difficulty in comparing and interpreting studies is that the accuracy depends on the assessed levels. A preponderance of lumbar levels tends to increase the overall rate of success since the pedicles of these vertebrae are larger and easier to be instrumented when compared to the thoracic levels. ${ }^{10}$ For this reason, even the published systematic reviews can not be taken in consideration as the real accuracy for all levels. ${ }^{22}$

We chose to use thoracic vertebrae due to the smaller diameter of the pedicles and a smaller available space for spinal cord at this 


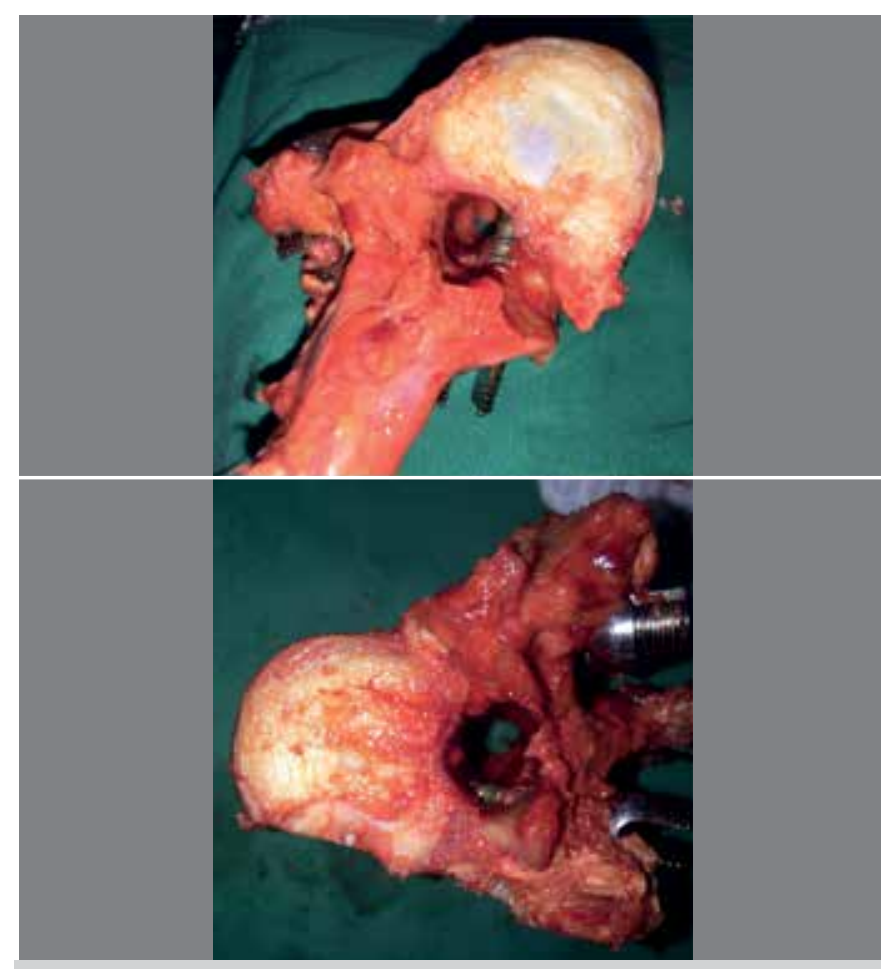

Figure 5. Dissection of the vertebrae that had a misplaced screw: fluoroscopy group in the left, navigation group in the right. level as compared with the lumbar levels. In the thoracic spine, the clinical consequences of a pedicle breach are more severe, with greater neurologic déficits. ${ }^{10}$ In fact, studies show that in the thoracic spine, lower accuracy rates are evidenced with the freehand technique, with fluoroscopy or navigation. ${ }^{8}$

Because computed-assisted navigation surgery is not a reality in our setting yet, we did not record or evaluate the time necessary for completing each procedure, and this could be considered a limitation of the present study. However, the literature is also controversial about surgical time comparisons between fluoroscopy or navigation-assisted surgeries of the spine. Some studies show increased surgical time of the computer-assisted navigation method when compared to the fluoroscopy ${ }^{13}$ but others conclude that, in trained hands, navigated surgery can present a shorter surgical time. ${ }^{20,23}$ Therefore, studies are needed to investigate the surgical time, bleeding and other potentially serious complications related to surgical time in the instrumentation of the thoracic spine using fluoroscopy or navigator-assisted methods.

\section{CONCLUSION}

The accuracy in the insertion of pedicle screws in the thoracic spine is equal comparing the computer-assisted navigation and fluoroscopy-assisted methods. As the safety of the procedure is greater for the surgical team with the navigation method, due to the absence of exposure to radiation, there is a need for randomized controlled trials in the clinical setting that evaluate other outcomes, such as the safety for the patient too, considering the surgical time and bleeding.

AUTHORS' CONTRIBUTIONS: Each author contributed individually and significantly to the writing of this paper. RPOB (0000-0002-1280-3746)* conception, design, acquisition of material, participation in experiments (surgery), interpretation of data, statistical calculation and writing of work. DAL (0000-0002-57021529)*: acquisition of material, participation in experiments (surgery), interpretation of data, statistical calculation and writing. JADL (0000-0002-1231-3368)* conception, design, interpretation of data, statistical calculation, critical review of intellectual property right and review and approval of the final version of the work. MAP (0000-0002-8817-4317)* data interpretation, critical review of what is intellectual and revision and approval of the final version of the work. ${ }^{*}$ ORCID (Open Researcher and Contributor ID).

\section{REFERENCES}

1. Belmont PJ Jr, Klemme WR, Dhawan A, Polly DW Jr. In vivo accuracy of thoracic pedicle screws. Spine (Phila Pa 1976). 2001;26(21):2340-6

2. Cotrel Y, Dubousset J. [A new technique for segmental spinal osteosynthesis using the posterior approach]. Rev Chir Orthop Reparatrice Appar Mot. 1984;70(6):489-94

3. Krag MH, Weaver DL, Beynnon BD, Haugh LD. Morphometry of the thoracic and lumbar spine related to transpedicular screw placement for surgical spinal fixation. Spine (Phila Pa 1976). 1988;13(1):27-32.

4. Katonis P, Christoforakis J, Kontakis G, Aligizakis AC, Papadopoulos C, Sapkas $\mathrm{G}$, et al. Complications and problems related to pedicle screw fixation of the spine. Clin Orthop Relat Res. 2003;(411):86-94

5. Gautschi OP, Schatlo B, Schaller K, Tessitore E. Clinically relevant complications related to pedicle screw placement in thoracolumbar surgery and their management: a literature review of 35,630 pedicle screws. Neurosurg Focus. 2011;31(4):E8

6. Mirza SK, Wiggins GC, Kuntz C 4th, York JE, Bellabarba C, Knonodi MA, et al. Accuracy of thoracic vertebral body screw placement using standard fluoroscopy, fluoroscopic image guidance, and computed tomographic image guidance: a cadaver study. Spine (Phila Pa 1976). 2003;28(4):402-13

7. Açikbas SC, Arslan FY, Tuncer MR. The effect of transpedicular screw misplacement on late spinal stability. Acta Neurochir (Wien). 2003:145(11):949-55.

8. Modi H, Suh SW, Song HR, Yang JH. Accuracy of thoracic pedicle screw placement in scoliosis using the ideal pedicle entry point during the freehand technique. Int Orthop. 2009;33(2):469-75

9. Schwarzenbach $O$, Berlemann $U$, Jost $B$, Visarius $H$, Arm E, Langlotz $F$, et al. Accuracy of computer-assisted pedicle screw placement. An in vivo computed tomography analysis. Spine (Phila Pa 1976). 1997;22(4):452-8

10. Puvanesarajah V, Liauw JA, Lo SF, Lina IA, Witham TF. Techniques and accuracy of thoracolumbar pedicle screw placement. World J Orthop. 2014;5(2):112-23.

11. Amiot LP, Lang K, Putzier M, Zippel H, Labelle H. Comparative results between conventional and computer-assisted pedicle screw installation in the thoracic, lumbar, and sacral spine. Spine (Phila Pa 1976). 2000;25(5):606-14.

12. Amato V, Giannachi L, Irace $C$, Corona $C$. Accuracy of pedicle screw placement in the lumbosacral spine using conventional technique: computed tomography postoperative assessment in 102 consecutive patients. J Neurosurg Spine. 2010;12(3):306-13.

13. Tabaraee E, Gibson AG, Karahalios DG, Potts EA, Mobasser JP, Burch S. Intraoperative cone beam-computed tomography with navigation (O-ARM) versus conventional fluoroscopy (C-ARM): a cadaveric study comparing accuracy, efficiency, and safety for spinal instrumentation. Spine (Phila Pa 1976). 2013;38(22):1953-8.

14. Villard J, Ryang YM, Demetriades AK, Reinke A, Behr M, Preuss A, et al. Radiation exposure to the surgeon and the patient during posterior lumbar spinal instrumentation: a prospective randomized comparison of navigated versus non-navigated freehand techniques. Spine (Phila Pa 1976). 2014;39(13):1004-9.

15. Kosmopoulos V, Schizas C. Pedicle screw placement accuracy: a meta-analysis. Spine (Phila Pa 1976). 2007;32(3):E111-20

16. Tian NF, Huang QS, Zhou P, Zhou Y, Wu RK, Lou Y, et al. Pedicle screw insertion accuracy with different assisted methods: a systematic review and meta-analysis of comparative studies. Eur Spine J. 2011;20(6):846-59.

17. Slomczykowski M, Roberto M, Schneeberger P, Ozdoba C, Vock P. Radiation dose for pedicle screw insertion. Fluoroscopic method versus computer-assisted surgery. Spine (Phila Pa 1976). 1999;24(10):975-82.

18. Rahmahtulla G, Nottmeier EW, Pirris SM, Deen HG, Pichelmann MA. Intraoperative image-guided spinal navigation: technical pitfalls and their avoidance. Neurosurg Focus. 2014;36(3):E3.

19. Laine T, Lund T, Ylikoski M, Lohikoski J, Schlenzka D. Accuracy of pedicle screw insertion with and without computer assistance: a randomised controlled clinical study in 100 consecutive patients. Eur Spine J. 2000;9(3):235-40.

20. Rajasekaran S, Vidyadhara S, Ramesh P, Shetty AP. Randomized clinical study to compare the accuracy of navigated and no-navigated thoracic pedicle screw in deformity correction surgeries. Spine (Phila Pa 1976). 2007;32(2):E56-64.

21. Mason A, Paulsen R, Babuska JM, Rajpal S, Burneikiene S, Nelson EL, et al The accuracy of pedicle screw placement using intraoperative image guidance systems. J Neurosurg Spine. 2014;20(2):196-203.

22. Gelalis ID, Paschos NK, Pakos EE, Politis AN, Arnaoutoglou CM, Karageorgos AC, et al. Accuracy of pedicle screw placement: a systematic review of prospective in vivo studies comparing free hand, fluoroscopy guidance and navigation techniques. Eur Spine J. 2012;21(2):247-55.

23. Guedes VP, Manffra EF, Aguiar LR. Cirurgia guiada por imagem na coluna vertebral: neuronavegação vs. fluoroscopia [Image-guided surgery in the spine: neuronavigation vs. fluoroscopy]. Coluna/Columna. 2015;14(3):181-5. 